\title{
The need for health in all policies in Canada
}

\author{
Paul Kershaw PhD
}

Cite as: CMAJ 2018 January 22;190:E64-5. doi: 10.1503/cmaj.171530

See related article at www.cmaj.ca/lookup/doi/10.1503/cmaj.170132

$\mathrm{H}$

ealth starts where we are born, grow, play, work and age, as established in a robust scientific literature summarized by the World Health Organization (WHO) Commission on the Social Determinants of Health. ${ }^{1}$ The social determinants are the distribution of wealth, income, education, employment and housing; food systems; human impact on the environment; power dynamics related to gender, class, race, sexuality, and so on; and the government policies that shape these other determinants. Accordingly, the WHO commission recommends "Health in All Policies," because health promotion is the domain of social, economic and environmental ministries, whereas medical ministries treat illness more than they prevent it.

In linked research, Dutton and colleagues quantify the degree to which social spending has a stronger positive influence on population health in Canada than does spending within health ministries. ${ }^{2}$ In Canada, per capita medical spending increased 10 times faster since 1981 than social spending did. Dutton and colleagues find that this trend is associated with lost opportunities to improve life expectancy and prevent avoidable mortality by comparison with a more even distribution between medical and social investments. These results add to evidence that should impel governments to seek better balance between medical and social expenditures.

Presently, such a budgetary rebalancing act is more complicated for governments that have aging populations because people need more medical care as they age or become frail. In Canada, the proportion of citizens aged 65 years and older increased from $8.4 \%$ of the population in 1976 to $16.5 \%$ today., ${ }^{3,4}$ This shift contributes to higher medical expenditures, as Canadian governments spend more than $\$ 13000$ per person aged 65 and older compared with less than $\$ 2500$ per person younger than 45 years. ${ }^{3}$ However, in an analysis about the effects of aging population on health care costs, Barer and colleagues showed in 1995 that population aging alone accounts for little of the increased use of health care by older people in Canada or other countries. ${ }^{5}$ Usage is driven more by the fact that the health system is doing more to and for older people than in the past, "suggesting that the appropriate care of elderly people should be a central issue for health care policy and management."

The age distribution of government spending and revenue collection demands more attention when we consider health in all policies. Since 1976, governments have increased annual spending on medical care, old age security and the Canada Pension Plan by

\section{KEY POINTS}

- Health promotion is the domain of social, economic and environmental ministries, whereas ministries of health treat illness more than they prevent it.

- Increased medical spending is not unambiguously good for population health when social spending does not keep pace.

- Healthy social spending and revenue collection should prioritize fair levels of investment for young and old alike without unduly diverting resources from one generation to another.

- A commitment to health in all policies invites analysis of public decisions that shape major costs of living, and encourages governments to collect revenue by taxing more what undermines the social determinants of health while taxing less what promotes them.

\$89.4 billion in 2016 (when measured as percent of gross domestic product), while increasing revenue by about half that amount. This spending-revenue gap coincided with an $\$ 18$ billion reduction in cumulative government spending on education, child care, parental leave and cash supports to families with children, along with substantial increases to government debt (budget numbers updated from 2011 figures provided by Smith and colleagues). ${ }^{6}$ These trends raise normative questions about whether Canadian governments are finding the right balance between investing in health promotion for the aging population and for younger cohorts. Dutton and colleagues invite such questions when they report no significant association between the social to health spending ratio in Canada and infant mortality, but do find significant associations between that ratio and life expectancy, as well as potentially avoidable mortality. ${ }^{2}$

Although the linked research focuses on spending, a commitment to health in all policies also invites review of government decisions that shape major costs of living. For instance, slowing the escalation of home prices is necessary to stabilize the social determinants of health. In 1976, average home prices cost four times the median earnings for a typical young Canadian, but now cost 10 times. Stabilization does not require additional public spending so much as adaptations to outdated policies that limit supply by restricting density in urban centres and augment demand by sheltering real estate wealth from taxation. ${ }^{7}$ The potential revenue from zoning and tax changes could support 
government efforts to rebalance the social to medical spending ratio even as the population ages, giving reason to link the new National Housing Strategy to the Health Accord.

Such insights show that tax collection strategies are integral to the health-in-all-policies concept, which recommends more taxation of what harms health (such as home prices outpacing earnings) and possibly less taxation of what promotes it (higher median earnings, for example). The Lancet Commission on Health and Climate Change applies this logic. Because climate change could be the greatest risk to human health, the Lancet Commission prescribes carbon taxation, to discourage reliance on fossil fuels and to pay to mitigate environmental damage. ${ }^{8}$

Beyond changes for governments, a commitment to health in all policies invites doctors to explore their role in shaping the social to medical spending ratio. The authors of the linked paper note that there are trade-offs between physician fee schedules and other social spending. This insight is important domestically, as Canadian doctors are well paid by international standards. ${ }^{9}$ Physicians should appreciate that containment of future increases in compensation or closure of tax advantages for doctors will promote population health by preserving funds for government agencies that focus on income, child care, housing, transit, the environment, and so on. Why? Because those agencies promote health more than medical ministries.

\section{References}

1. Commission on the Social Determinants of Health. Closing the gap in a generation: health equity through action on the social determinants of health [report]. Geneva: World Health Organization; 2008. Available: www.who.int/ social_determinants/thecommission/finalreport/en/index.html (accessed 2017 Dec. 27).

2. Dutton DJ, Forest P-G, Kneebone RD, et al. Effect of provincial spending on social services and health care on health outcomes in Canada: an observational longitudinal study. CMAJ 2018;190:E66-71.
3. CANSIM Table 051-0001: Estimates of population, by age group and sex for July 1, Canada, provinces and territories, annual. Ottawa: Statistics Canada; 2017. Available: http://www5.statcan.gc.ca/cansim/a26?id=510001 (accessed 2018 Jan. 5).

4. Kershaw P, Anderson L. Measuring the age distribution in Canadian social spending. Can Public Adm 2016;59:556-79.

5. Barer ML, Evans RG, Hertzman C. Avalanche or glacier? Health care and the demographic rhetoric. Can J Aging 1995;14:193-224.

6. Smith N, Mitton C, Kershaw P. The reallocation challenge: containing Canadian medical care spending to invest in the social determinants of health. Can J Public Health 2016;107:e130-2.

7. Kershaw P. Code Red: B.C. is the worst performing economy in Canada for younger generations. Vancouver: Generation Squeeze; 2017. Available: http:// bit.ly/GS_BCworsteconomy (accessed 2017 Dec. 27).

8. Watts N, Adger WN, Agnolucci P, et al. Health and climate change: policy responses to protect public health. Lancet 2015;386:1861-914.

9. Health at a glance 2017: OECD indicators. Paris: Organisation for Economic Cooperation and Development Publishing 2017. Available: http://oecd-ilibrary.org/ social-issues-migration-health/health-at-a-glance-2017_health_glance-2017-en (accessed 2017 Dec. 27).

Competing interests: Paul Kershaw is the founder of Generation Squeeze, a nonprofit, university-community collaboration located at three institutions: his laboratory at the University of British Columbia, the Vancity Community Foundation (VCF) charity, and the nonprofit Association for Generational Equity (AGE). Kershaw is the unpaid chair of a volunteer advisory group for the VCF, and the unpaid chair of the volunteer board of AGE. Generation Squeeze receives funds to support its community engagement activities from the Vancouver Foundation, United Way of the Lower Mainland, Vancity Credit Union, Friends of the Greenbelt Foundation, Wesgroup and the Urban Development Institute. Commercial interests do not provide any funding for Generation Squeeze research, nor contribute to Paul Kershaw's salary at his UBC laboratory.

This article was solicited and has been peer reviewed.

Affiliation: Generation Squeeze, and School of Population and Public Health, University of British Columbia, Vancouver, BC

Correspondence to: Paul Kershaw, paul.kershaw@ubc.ca 